kept waiting in that room most of the time; and had $I$ any funking propensities, alas! for the result. Gladly did I hril my rumber being called when I had to undergo the usual questioning on surgery and pathology. It affords me unbounded pleasure to state that one of the examiners, who still has a spark of feeling for others, expressed his regret that I should be kept waiting so long. and, when unable to answer a question, said that it was not surprising, and hence gave me credit for it; in fact, my memory was sadly at a discount.

After this $I$ was ushered into a still smaller room, the library, I imagine, where I found the remainder of the candidates. We were then in a glorious state of uncertainty, each one for himself reflecting upon his answers, thereby trying to prove to himself that he had done well. At this juncture it became too exciting for me, and hence I forgot to note the time spent bere previous to being called out. We were at length summoned like dumb lambs to the slaughter, not knowing whether we were plucked or nct, nor did we dare open our mouths by way of enlightening our darkness. After more delay we signed our namesto some document (it is to be honed they know my signature ere this). Then, in a very solemn and catholic sort of manner we were ushered in one by one into a sanctum where the examiners sat in state; and on seeing the men standing in a line, similar to so many Sunday-school children, it quite overcame me, and I was compelled to relieve myself with a good round of laughter, which was immediately stopped. My expectations rose high while standing thus, imagining they wonld place a piece of cake or something similar into our hands, but was donmed to be disappointed. I find it would have been a great insult to ask for a seat. The President in a solemn tone adiressed us, but I was too ill at ease to hear or mind his words. To my great relief we were then allowed to depart, and could get our diplomas on the morrow.

Such is the ordeal I have undergone to obtain the M.R C.S. The hardships and uncourteous treatment gone through are sufficiently patent, and require no comment on my part. I am, Sir, your obedient servant,

Angust 10th, 1871. A. SUCCESSFul M.R.C.S.

\section{DETENTION OF ALLEGED LUNATICS.}

\section{To the Editor of THE LANCET.}

SrR,-Respecting a notice which appeared in THe LANCET a few weeks since, in which a question was raised as to the power of the Lords Justices to order the release of a reported lunatic, \&c., I beg to inform you that the matter was ultimately carried before the Lord Chancellor, who expressed himself strongly on the case, and wrote to the Commissioners in Lunacy on the suhject, and at his recommendation the reported lunatic was allowed leave of absence from the asylum (in which he has been detained about two years) for the space of three or four months, during which time he is to be visited by the Commissioners, at my residence in Brecknock-road.

It thus appears that neitber the Lords Justices nor the Lord Chancellor have power to order the release of an alleged lunatic, if the Commissioners in Lunacy ohject; and I consider the present case a strong instance why the Lunacy Lins should be altered. I consiler this case highly interesting to the medical profession, as in my opinion the alleged luuatic is perfectly sane, and has been most unfairly detained.

Any further information I shall be glad to afford, either at 40, Endell-street, or 142, Brecknork-road.

I am, Sir, your obedient servant,

$$
\text { Augast, 1871. W. FAULKNER, M.R.C.S. }
$$

\section{SEQUELA OF S M A L L - P OX.}

To the Editor of THE LANCET.

Srr,-I send the following "short abstract of a case illustrating the secondary consequences of small-pox." It occurred during the present epidemic. C. A-, aged six months, well formed and plump (vaccinated successfully when three months old), took small-pox, which was going through the family. The symptoms were mild, and the eruption discrete. On the morning of the seventh day, however, the nurse noticed a large patch of phleumonous erysipelas on the right buttock. This communicated a brawny feel to the touch. The surface of the swelling was generally red, but there was a livid spot in the centre. On the next day vesication and separation of patches of cuticle bar taken place, and the whole surface was purple. The infant, however, continued to take its fond, and lingered till the fourth day of the invasion of erysipelas, and the eleventh of small-pox. I onght, perhaps, to ard that the mother bad erysipelas (not phlegmonous) in the last month of pregnancy, which might possihly act as a predisposing cause of the disease in the case of the child.

I am, Sir, yours obediently,

Blackheath, July 28th, 1871. J. Harmar Siri'rH, M.R.C.S.

IRELAND.

(FROM OUR OWN CORRESPONDENT.)

THE THREATENED APPROACH OF CHOLERA.

CoNsiderable apprehension has arisen at Drogheda, not altogether groundless, considering the ravages made there from former visitations of this dreaded dicease. On Thursday last the Market Jury brought the suhject of the watersupply under the notice of the Mayor, who, after consulting with the Waterworks Company, declined to move in the matter. The following day the Jury again met, and passed a resolution to the effect that in their npinion the water now supplied by the Drogheda Waterwor'ks Company is utterly unfit for buman use, and calculated to creste digease. Memorials were also adopted to be forwarded to Earl Spencer, the Drogheda guardians, and the magistrates of the district, praying that the most urgent efforts be at once aropted for the abatement and removal of a nuisance so highly dangerous, not only to consumers of the contaminated water, but to the community at large. The majority of towns in Ireland are indeed wretchedly supplied with pure water. Among others I may mention that of Morivea, situate about a d zen miles from Gal way. In this village, except bog-water, there is no supply nearer than a spring some miles distant, there boing no pump or well in the village; and there are numerous otber towns in Connaught in no better condition. What wonder is it, then, that in an epidemic of cholera or fever the mortality should be so excessive?

\section{A NEW ANTISEPTIC}

Dr. Emerson Reynolds, attached to the Laboratory of the Royal Dublin Society, has lately suggested the use of the sulphite of zinc as an antiseptic and deodoriser, and considers that its power of checking decomposition, and absorbing sulphuretted hydrogen and other noxious gases, renders it useful as a sanitary agent. It can be prepared at a cheap rate by treating the refuse zinc oxide from brass foundries or zine factories with sulphurous acid in presence of water. It is also inodorous, and not liable to rapid change. The only matter requiring elucidation is as regards its poisonous properties, for shonld it not be harmless its use can never be expected to become general, especially when deaths from poisonous deodorising preparations have of late become so unfortunately frequent.

\section{HEALTH OF IRELAND.}

From the Report of the Registrar-General for Treland for the first quarter of the year, only issued within the last few days, I find that the birtbs registered during that period anounted to 41,637 , affording an annual ratio of 1 in every 32.4 , or 308 per cent. of the population by the last Census; and the number of registered deaths to 26,510 , being equal to an annual ratio of 1 in 510 , or 1.96. The RegistrarGroneral states that it is but too apparent from the foregoing figures that the registration of birtbs and deatbs is still very imperfect, the annual ratio of births to the estimated population in England being about 1 in 29 or 30 , and of deaths 1 in 44 or 45 ; whilst in Ireland, according to the present return, the ratios are-for birtbs, 1 in 324 , and for deaths, 1 in 51. Now, as the registration of deaths is so defective, would it not be a good plan to have a law that no body shonld be buried in this country until a certificate of death had been handed to the officiating minister or 